[8] Stoliarova, M. A., Zherdeeva, O. V. (2014). Metodycheskye aspekty effektyvnosty yspolzovanyia zemelnykh resursov selskokhoziaistvennoho naznachenyia. Nauchnyi zhurnal KubHAU [Scientific journal of KubSU], 96 (2). Available at: http://ej.kubagro.ru/2014/02/pdf/20.pdf

[9] Belinska, S. M. (2015). Teoretychni zasady bukhhalterskoho obliku zemli. Biznes-navihator [Business Navigator], 1 (36), 168-173.

[10] Kireitsev, H. H., Ivanishhenko, L. O.; Ghrevcov, V. D. (Ed.) (1987). Oblik osnovnykh zasobiv u silskohospodarskykh pidpryiemstvakh. Kyiv: Urozhai, 176.

[11] Kushnirenko, Iu. A. (2013). Oblik ta opodatkuvannia zemel silskohospodarskoho pryznachennia: kontseptualnyi pidkhid. Ahroinkom, 7, 76-80.

[12] Vinichenko, I. I., Soroka, Iu. O. (2015). Efektyvnist vykorystannia resursnoho potentsialu silskohospodarskykh pidpryiemstv. Investytsii: praktyka ta dosvid [Investments: practice and experience], $22,34-37$.

[13] Sakal, O. V. (2013). Oblik zemelnykh resursiv yak peredumova efektyvnoho zemelnoho administruvannia. Heodeziia, kartohrafiia i aerofotoznimannia [Geodesy, cartography and aerial photography], 77, 87-91.

[14] Belinska, S. M. (2015). Metodychni aspekty otsinky zemelnykh resursiv dlia tsilei bukhhalterskoho obliku. Efektyvna ekonomika [Effective economy], 3. Available at: http://www.economy.nayka.com. ua/?op=1\&z=3915

[15] Hulinchuk, R. M. (2015). Metodychni osnovy otsinky potentsialu ta efektyvnosti vykorystannia zemel silskohospodarskoho pryznachennia. Zbalansovane pryrodokorystuvannia [Balanced nature management], 2, 107-113.

\title{
INVESTIGATION OF CONDITIONS AND BENEFITS FOR UKRAINE IN THE TRANSITION OF ITS HOUSEHOLD IN THE RANK OF THE INTERNAL INVESTOR OF THE STATE
}

\author{
Yuliya Bondarenko \\ Department of Management of Organizations \\ Institute of Economics and Management \\ Lviv Polytechnic National University \\ 12 Bandera str., Lviv, Ukraine, 79013 \\ Yulia.Bond@gmail.com \\ Tetiana Kulinich \\ Department of Management of Organizations \\ Institute of Economics and Management \\ Lviv Polytechnic National University \\ 12 Bandera str., Lviv, Ukraine, 79013 \\ tculia@gmail.com
}

\footnotetext{
Abstract

In the article the place, role and functions of families (households) as economic subjects of the market system are clarified. The interrelation, interdependence of categories of "savings", "investments" and "consumption" is defined. The importance and location of the internal investor in the investment process at the macroeconomic level is proved. The algorithm for determining the level of aggregate income of a family necessary for transition to the rank of an internal investor of the state is presented. Parallels are drawn between the author's theoretical and methodical approach proposed in the article and between the theories (laws, models) of a number of well-known economists, such as E. Engel, M. Tugan-Baranovsky, J. Keynes, P. Samuelson and others. The features of practical definition of the minimum level of the aggregate income of a family and a household for savings and investments for Ukrainian realities are revealed. The current and desired operating conditions and the results of financial and economic development of each of the interested parties are considered. In particular, for the population it is shown how, based on its real income, to identify and plan expenditures in order to move to investments. In addition, it is investigated: first, what exactly is the real minimum level of income per month will allow one person or a family (of two, three, four people) to survive in the economic conditions that defined
} 
public authorities and formed the market; secondly, what exactly need s a person or a household to be able to meet at an appropriate level of income; thirdly, what level of income will allow the population to save and convert these savings into investments (with their subsequent distribution for the development of domestic business and entrepreneurship). At the same time, it is shown how the state (on Ukrainian data) can influence the growth of domestic investment in order to reduce the deficit of financial resources for the development of business and the economy of the country.

Keywords: investments, internal investor, investment process, savings, consumption, household/family income.

\section{Introduction}

Income as an economic category is one of the main resources that materially ensures the existence of the population and contributes to the effective development of the state as a whole. The most important, and sometimes determining role in the income of the population of Ukraine is pay (about $40 \%$ according to data from 2001-2016 [1]). It is the level of wages that characterizes the ability of the population to satisfy its spiritual and material needs, being reflected through the function of consumption. It is the aggregate income of families and households that determines the level of life and well-being of the country's population, while the latter, in turn, is summarized in the indicator of the standard of living of the population as a whole, through the general human development index (HDI). The importance of the HDI for Ukraine is emphasized by its rather low rating behind it (84 among 188 states at the end of 2016 [2]).

However, to assess the country's development potential, it is not the income level of its population that is averaged and normalized using the indices, that is important. A more significant factor characterizing the standard of living in the country and the welfare of its population is the opportunity to save under equal current economic conditions. For each country there is a structure of family expenses, in which it is important to allocate a component of savings, which under favorable conditions is transformed into investment, serve as a generator of economic development of the state.

Therefore, it is important to investigate this starting point of such development, the lever that launches it. That is, analyze the specifics of the formation of the investment component in savings, and savings in wages, and their impact on the effective development of the state. In particular, despite the existence of a kind of feedback in this mechanism, since the state through the stimulation of the emergence of savings creates additional conditions for the reproduction and development of labor, economic and investment potential of its population.

\section{Analysis of recent research and publications}

The study of elements and participants in the logical chain of "income - savings - investments" at various economic levels has always attracted the thoughts of numerous scientists and practitioners. So, the classic of economic thought E. Engel, back in the XIX century has drawn up a law according to which there is a close relationship between the income level and the family's expenditure structure, and an there is inversely proportional relationship between the proportion of the national income spent on consumption and the level of welfare of the population [3].

This view is complemented by the arguments of the prominent Ukrainian economist M. Tugan-Baranovsky [3], who refuted K. Marx's assertion that profit and wages are in the opposite relationship to each other, and proved that with the growth of profits, and, accordingly, the state's revenues. He also argued that wages and profits can increase with productivity growth. This, in turn, increases the financial capacity of the state, entrepreneur and employee. The combination of these provisions of the theory of crisis enabled the scientist not only to show the regularities of the emergence of crises, but also to overcome them through the activation of the investment and social policy of the state.

The latter corresponds to the key opinion of A. Wagner [4] on the need for the participation of state finances in regulating the reproduction processes in the country's economy, while ensuring the movement of incomes and the changing level of their well-being.

J. Keynes managed to combine the thoughts of previous outstanding scientists. Thus, he used the achievements of Wagner and explored the process of forming the basis for regulating the 
reproduction of the economy and proved the slowdown of development or even the impossibility of the existence of free enterprise without active state intervention in development of socio-economic processes and/or without significant expansion of its (state) functions [5, p. 150].

In turn, the concepts of M. Tugan-Baranovsky formed the basis for the theory of forecasting market conditions developed by J. Keynes for the conduct of effective state economic policy. As a result, a law was drawn out, according to which people tend to increase consumption with income growth, but not as much as income. Because Keynesian income is consumption + investment; preservation $=$ income - consumption; hence the conservation $=$ investment $[5, p .118]$. That is, only the predominance of the aggregate increase in income over consumption, which can be called a partial "preservation" of this income, allows to proceed to investing.

Economist Paul Samuelson went further and first applied higher mathematics to develop consumption and investment models, which are still used today to assess the potential of the economies of countries [6, p. 156]. In his view, nations that consume a significant part of their income and, correspondingly, invest relatively little, are characterized by moderate rates of economic growth (USA) and vice versa. Nations that consume a small fraction of their income invest heavily, and therefore they have high rates of economic growth and labor productivity (Japan, South Korea).

The application of the above-mentioned classical theories in Ukrainian practice can be traced on the example of publications of a number of Russian scientists. Thus, scientists S. Panchishin, M. Savluk, S. Vatamaniuk [7] focused on studying the relationship between the trends in the formation of incomes and savings in the period of formation of the transitional economy of Ukraine. L. Kliuchnik [8] summarized theoretical approaches to the use of household savings as a source of investment resources of the Ukrainian economy. I. Petrenko [9] studied the experience and highlighted the problems that accompany the transformation of the savings of the Ukrainian population into investments at the present stage.

However, so far insufficient attention has been paid to the algorithmization of the process of determining the minimum level of the aggregate income of families (households) for savings and investment under different conditions and circumstances, and the impact of aggregate structured family income on the development of entrepreneurship and the state (as well as their feedback).

\section{Aim of research}

Theoretical substantiation and practical formation of the algorithm for determining the minimum level of the aggregate family income necessary for its transition to the rank of the state's domestic investor, with the subsequent distribution of these funds as additional capital investments in the development of domestic business and the economy (by the example of Ukraine).

\section{Research of the preconditions and consequences of the transition of households to the rank of an internal investor of the state}

The determining element in the system of macroeconomic management of investment activity is the regulation of the formation and distribution of the state's own investment opportunities. Therefore, the priority task of the relevant state authorities, in particular the government, in our opinion, is the creation of effective instruments of economic policy, which would regulate and balance the supply and demand of investment resources. Currently in Ukraine there is no type of economic activity (TEA), which would not need investment resources to accelerate its development. Moreover, for many TEA these additional financial and material resources are an extremely important issue of their maintenance in crisis conditions and survival.

The level of supply of these resources is formed in the investment market because of such subjects of the economy that attract temporarily idle funds, the main representatives of which are financial and credit institutions and investment intermediaries. If to limit ourselves to domestic investments, then the funds in these institutions can come from the domestic business and from the resident population. The problem is primarily the formation of investment resources in the required volume, and only then their distribution. First of all, let's consider the situation when the key figure of these processes is the family (households), which under favorable circumstances can become domestic investors. 
The authors consider the concept of family and household as having more identical than distinctive features, both in terms of obtaining and in terms of using (distributing) the received revenues, coincides with the considerations of a number of classics of economic thought [3].

So, the basis of our study is the minimum size of the aggregate income of the family, which would cover the costs of a potential domestic investor at the expense of this income and reach a level at which it would be possible to make savings. In the future, such savings should (under the creation of conditions) turn into investments, as savings are that part of incomes that are not consumed. At the same time, if consumption is understood as "the cost of purchasing goods and services to meet the needs" [6, p. 157], then this leads to a direct and rather close relationship between consumption and saving, namely: savings are "... part of the income that is not consumed" [6, p. 159]. So, an undeniable fact is that savings are the only source of investment resources, and the size of investment activity in the state is determined precisely by the amount of savings of the population [7, p. 339].

The abovementioned main provisions of classical theories not only explain the interconnection and interdependence of such categories as investment, savings, consumption and income, but in combination with contemporary facts are the most important argument for creating conditions for increasing domestic investment. For this, in our opinion, it is necessary first of all to analyze the model of individual consumption. So, consumption is the simplest and most weighty component of the gross national product (GNP) [3]. With formalized representation through components, GNP is an indicator of the national production of goods and services, which covers consumption (Z), gross private domestic investments (U), government purchases of goods and services (V), net exports (E), i. e. GNP=Z+U+V+E. Let's note that the lion's share in GNP belongs exactly to consumption, insignificant - to investments. Unfortunately, net exports (for most cases) are the smallest. Consequently, the consumption function is one of the most important in macroeconomics. It shows the relationship between consumer spending and tax-free income in both statics and dynamics.

Thus, consumption is the main component of aggregate expenditure, and savings - when properly used, are transformed into investments, which are the condition for long-term economic growth. It is this tandem in combination that creates the simplest model for determining income the multiplier model. An important and at the same time the main is the mechanism of distribution of income for consumption and savings. Today, the lion's share of income, and in most families, all income is used for consumption. In particular, given the dynamics of the minimum and average wages in Ukraine over the past 5 years (Table 1).

\section{Table 1}

The level of minimum and average wages in Ukraine for the month

\begin{tabular}{ccccccc}
\hline Years & & $\mathbf{2 0 1 3}$ & $\mathbf{2 0 1 4}$ & $\mathbf{2 0 1 5}$ & $\mathbf{2 0 1 6}$ & $\mathbf{2 0 1 7}$ \\
\hline \multirow{2}{*}{ Minimum wage } & UAH & 1218 & 1218 & 1264.7 & 1429.3 & 3200 \\
Average wage in Ukraine & USD & 149.2 & 103.3 & 55.0 & 54.9 & 119.8 \\
For reference, the average rate UAH/USD & UAH & 3263.8 & 3453.7 & 4156.6 & 5210.5 & 6799.3 \\
FSD & 399.7 & 291.1 & 180.3 & 200.2 & 262.6 \\
& 8.17 & 12.27 & 23.48 & 26.06 & 26.72
\end{tabular}

Note: calculated according to NBU rate: (UAH/USD) [10, 11$]$ (according to the average chronological with a period-a month)

Usually, the minimum wage is set in such way that it is not less than the cost of living, because any person, while engaged in work, must ensure the restoration of his own vital forces. However, in our country, as a result of exposure and manifestation of a set of macroeconomic threats, there was a significant devaluation of the hryvnia. In the indicated devaluation of the hryvnia (as of 1.01.2014), the minimum Ukrainian wage was at the level of $\$ 150$ (70 positions at the bottom of the rating), almost the same amount was paid by workers of former Asian post-Soviet states - Turkmenistan or Azerbaijan. But after a sharp drop in the hryvnia, the minimum wage in Ukraine in 
2015-16 fell to \$ 55 (see Table 1), and African countries like Liberia, Botswana and the Democratic Republic of Congo [12] have become "neighbors" in terms of indicators.

Raised in 2017 year to the level of 3200 UAH (120 \$ or 100 euros) it still remains very low. For comparison, in the European Union, the lowest minimum wage (as of 1.01.2017) - in Bulgaria it is 235 euros, the highest in Luxembourg - 2 thousand euros [13]. According to the Ukrainian minimum wage is half the lowest in the EU and almost 20 times lower than the highest.

Analyzing the above, it is decided to establish the level of minimum income per person, at which an ordinary Ukrainian could save with a minimum earnings of $3200 \mathrm{UAH}$ (for the calculations, the income level and tariffs were taken in 2017) and the average earnings of $6800 \mathrm{UAH}$ (for the Lviv region - 6287 UAH.).

Calculations take into account a different combination of conditions: the number of people in the family, the size of expenses for a representative (which varies depending on the increase in the number of family members and their qualitative composition).

Thus, knowing the minimum aggregate income of the family, it is determined at what level of the aggregate income the family (household) can save (the income level will increase, but the costs will also increase, so the error will be small). For this purpose, the authors present a graphical model of the algorithm in the form of a flowchart and, using the $\mathrm{C} / \mathrm{C}++$ programming language and Excel programs, calculate the surplus funds that the family or household will receive and can use it as savings.

The basis of the equation of J. Keynes [5], which shows that part of the household income goes to personal consumption (C), while the excess takes the form of savings $(S)$ : $Y=Z+S$, where $\mathrm{Y}$ - the total income of the family, $\mathrm{Z}$ - consumption, $\mathrm{S}$ - savings.

It follows that income is the main factor that forms not only consumption (part of the income that can be used or spent for various needs), but also savings. Let's consider in detail and divide into categories consumption and saving factors.

Priorities in consumption are different for all people. However, the most common for most groups and types of population (families) of the cost group (costs) are identified, which are placed according to their significance for people (in view of the well-known Maslow demand definition pyramid [3]) and divided them into categories A, B, C, D, S, G and the components of these categories are the factors: $a_{i}, b_{k}, c_{l}, d_{p}, s_{q}, g_{s}$. So, let's obtain the following distribution:

1) A (mandatory monthly expenses):

$$
A\left(a_{1}, a_{2} \ldots a_{i} \ldots a_{n}\right)=\sum_{i=1}^{n} a_{i}
$$

where $a_{1}-$ food, $a_{2}-$ utility payments, $a_{3}-$ taxes, $a_{4}-$ transport, $a_{5}-$ industrial goods (clothing, chemistry), $a_{6}-$ telecommunications services, $a_{7}$ - child development, $a_{8}-$ other; $i=\overline{1, n}$; $\mathrm{n}_{\text {min }}=5, \mathrm{n}_{\text {max }}=8$;

2) B (recurrent costs):

$$
\mathrm{B}\left(\mathrm{b}_{1}, \mathrm{~b}_{2} \ldots \ldots \mathrm{b}_{\mathrm{k}} \ldots \mathrm{b}_{\mathrm{m}}\right)=\sum_{\mathrm{k}=1}^{\mathrm{m}} \mathrm{b}_{\mathrm{k}}
$$

where $b_{1}$-loans and bank services, $b_{2}$ - insurance, $b_{3}$ - home appliances, $b_{4}$ - repair, $b_{5}-$ medical services, $\mathrm{b}_{6}$ - other; $\mathrm{k}=\overline{1, \mathrm{~m}} ; \mathrm{m}_{\min }=2, \mathrm{~m}_{\max }=6$;

3) $\mathrm{C}$ (optional costs):

$$
C\left(c_{1}, c_{2} \ldots c_{1} \ldots c_{f}\right)=\sum_{l=1}^{f} c_{1} \text {, }
$$

where $c_{1}$ - the acquisition of luxury goods, $c_{2}-$ the cost of entertainment, $c_{3}$-rest and recreation, $\mathrm{c}_{4}$ - education, personal development (books, magazines, seminars), $\mathrm{c}_{5}-$ another; $1=\overline{1, \mathrm{f}}$; $\mathrm{f}_{\min }=1, \mathrm{f}_{\max }=5$ 
4) D (unplanned costs):

$$
D\left(d_{1}, d_{2} \ldots . . d_{p} \ldots d_{h}\right)=\sum_{p=1}^{h} d_{p},
$$

where $\mathrm{d}_{1}$-donations and volunteering, $\mathrm{d}_{2}$ - holidays (organization, participation), $\mathrm{d}_{3}$ - other (for example, family expenses); $\mathrm{p}=\overline{1, \mathrm{~h}} ; \mathrm{h}_{\min }=1, \mathrm{~h}_{\max }=3$;

5) $\mathrm{S}$ (savings and investments):

$$
\mathrm{S}\left(\mathrm{s}_{1}, \mathrm{~s}_{2} \ldots \mathrm{s}_{\mathrm{t}} \ldots \mathrm{s}_{\mathrm{q}}\right)=\sum_{\mathrm{t}=1}^{\mathrm{q}} \mathrm{s}_{\mathrm{t}}
$$

where $\mathrm{s}_{1}$ - bank deposits, $\mathrm{s}_{2}$ - savings saved in cash, $\mathrm{s}_{3}$ - investments in securities and investment funds, $\mathrm{s}_{4}-$ development of their own business, $\mathrm{s}_{5}$ - other; $\mathrm{t}=\overline{1, \mathrm{q}} ; \mathrm{q}_{\min }=1, \mathrm{q}_{\max }=5$;

6) $\mathrm{G}$ (income/return on investment):

$$
G\left(g_{1}, g_{2} \ldots \ldots g_{x} \ldots g_{e}\right)=\sum_{x=1}^{e} g_{x}
$$

where $g_{1}$ - interest on bank deposits, $g_{2}$ - dividends from investing in securities and investment funds, $\mathrm{g}_{3}$ - profit from running own business (at different levels of activities profitability $(\mathrm{R})), \mathrm{x}=\overline{1, \mathrm{e}}$.

As a result, a mathematical model for determining the minimum level of the aggregate family income necessary for its transition to the rank of an internal investor of the state is proposed. It looks like:

$$
\begin{gathered}
Y=Z+\sum_{t=1}^{q} s_{t} \\
Z=\left[\sum_{i=1}^{n} a_{i}+\sum_{k=1}^{m} b_{k}+\sum_{l=1}^{f} c_{1}+\sum_{p=1}^{h} d_{p}\right],
\end{gathered}
$$

where $\mathrm{Y}$ - the aggregate income of the family; $\mathrm{Z}$ - total family expenses;

$$
\begin{gathered}
\mathrm{Y}=\left[\sum_{\mathrm{i}=1}^{\mathrm{n}} \mathrm{a}_{\mathrm{i}}+\sum_{\mathrm{k}=1}^{\mathrm{m}} \mathrm{b}_{\mathrm{k}}+\sum_{\mathrm{l}=1}^{\mathrm{f}} \mathrm{c}_{\mathrm{l}}+\sum_{\mathrm{p}=1}^{\mathrm{h}} \mathrm{d}_{\mathrm{p}}\right]+\sum_{\mathrm{t}=1}^{\mathrm{q}} \mathrm{s}_{\mathrm{t}} ; \\
\mathrm{Y}+\sum_{\mathrm{x}=1}^{\mathrm{e}} \mathrm{g}_{\mathrm{x}}=\mathrm{Z}+\sum_{\mathrm{t}=1}^{\mathrm{q}} \mathrm{s}_{\mathrm{t}} ; \\
\sum_{\mathrm{t}=1}^{\mathrm{q}} \mathrm{s}_{\mathrm{t}} \rightarrow \max , \sum_{\mathrm{x}=1}^{\mathrm{e}} \mathrm{g}_{\mathrm{x}} \rightarrow \max . \\
(\mathrm{Z} \rightarrow \min ) \mathrm{V}(\mathrm{Y} \rightarrow \max ) \mathrm{V}(\mathrm{Z} \rightarrow \min \wedge \mathrm{Y} \rightarrow \max ) \Rightarrow \\
\left.\Rightarrow\left(\sum_{\mathrm{t}=1}^{\mathrm{q}} \mathrm{s}_{\mathrm{t}} \rightarrow \max \wedge \sum_{\mathrm{x}=1}^{\mathrm{e}} \mathrm{g}_{\mathrm{x}} \rightarrow \max \right)\right) ;
\end{gathered}
$$

For a better understanding of this model, let's build an algorithm, that is, a flowchart for determining the minimum level of the aggregate family income necessary for transition to the rank of the domestic investor of the state (Fig. 1), where det* is determined.

Additionally, using the programming language $\mathrm{C} / \mathrm{C}++$, situations are simulated with the formation of excess or lack of funds, various expenses and incomes are considered: per person per month, for different types of households. 


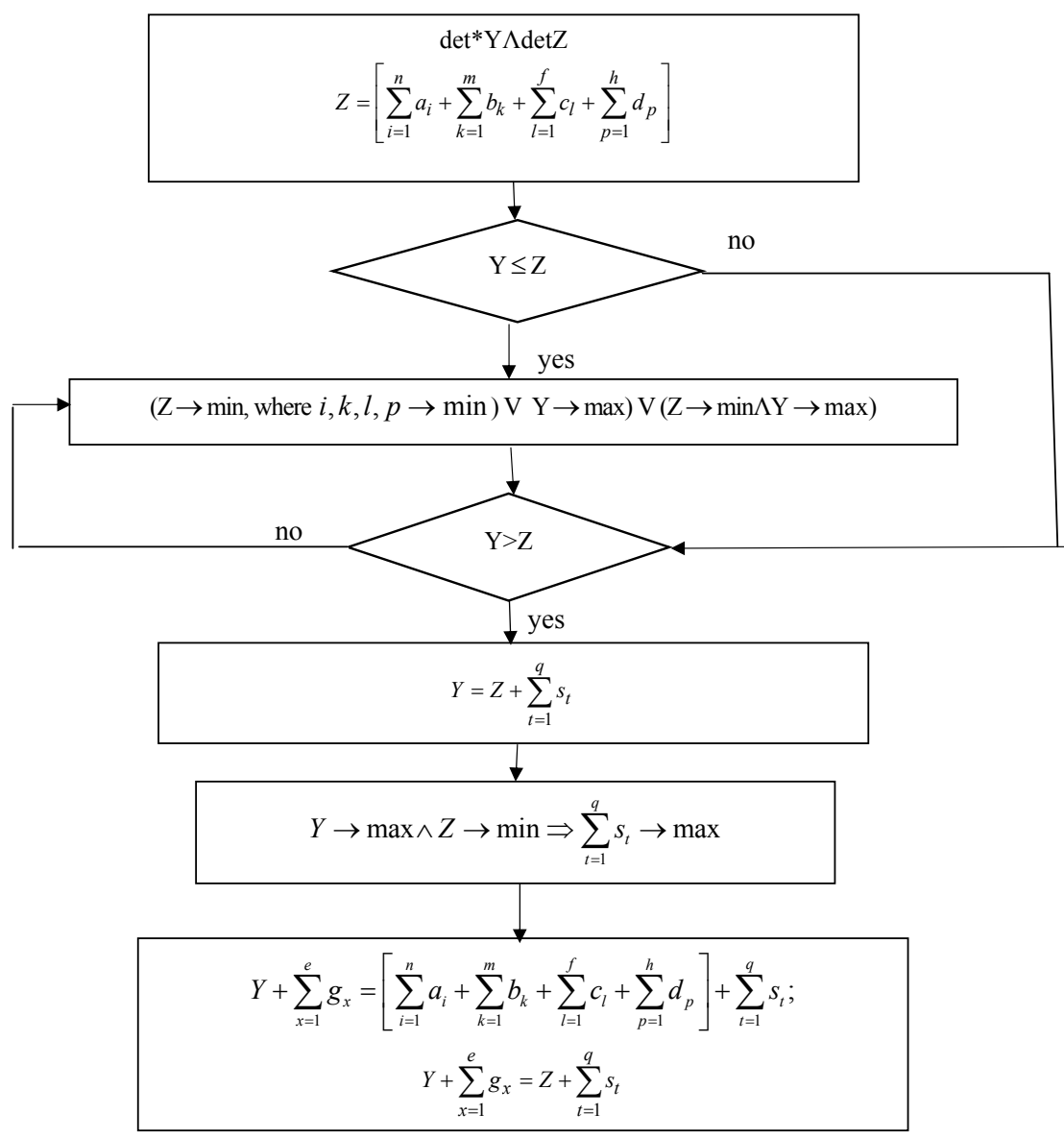

Fig. 1. A block diagram of the definition of the minimum level of the aggregate income of a family necessary for transition to the rank of an internal investor of the state (own development)

Also, a survey in Google is used to identify the distribution of costs, the formation of savings and investment by Ukrainian households. The survey involved 227 households. Before processing the results, restrictions were made: only those households consisting of working people of working age and condition (with working pensioners inclusive). At the same time, children at school and preschool age are considered. Among those surveyed, only those who believe that they lead an economical way of life (can call themselves "provident") are selected and are eager to invest in their future. According to the so-called "rich" households, the level of income in which per 1 worker is a large 9 thousand UAH is left without attention. As a result, there are 181 households left and 5 types are identified, most represented in the course of such questionnaire:

1) households, consisting of 1 person, who receives a minimum level of income (12\% of respondents); including:

2) 4 types of households that can be assessed as having an average level of income (81\%),

a) $15 \%$ consist of 1 working person;

b) $21 \%$ - of 2 working without children;

c) $35 \%$ - of 2 working with 1 child;

d) $10 \%$ - of 2 working with 2 children.

The other respondents ( $7 \%$ ) who isn't enter any of the above categories include such combinations:

1) 1 working and 1 child;

2) 2 in working order and age, of which 1 is working and 1 is unemployed without children and/or with children;

3) households, where more than 2 children). 
The survey collected data for 2017 the data are averaged. For calculations, the Ms Excel program is applied. The costs are allocated to the categories indicated above. The factors of the additive model are identified. The results are summarized in Table 2.

Table 2

The average estimation of investment opportunities of 5 types of domestic households according to 2017

\begin{tabular}{|c|c|c|c|c|c|c|c|c|c|c|c|c|c|}
\hline \multirow{3}{*}{\multicolumn{3}{|c|}{$\begin{array}{l}\text { Categories } \\
\text { by classi- } \\
\text { fication of } \\
\text { needs }\end{array}$}} & \multirow{3}{*}{ Factors } & \multirow{2}{*}{\multicolumn{2}{|c|}{$\begin{array}{c}\begin{array}{c}\text { Minimum } \\
\text { wage level } \\
(2017)\end{array} \\
\begin{array}{c}\text { Household of } \\
1 \text { person } \\
\text { (worked) }\end{array}\end{array}$}} & \multicolumn{8}{|c|}{$\begin{array}{l}\text { Average wage level } \\
\text { (data of 2017) }\end{array}$} \\
\hline & & & & & & \multicolumn{2}{|c|}{$\begin{array}{l}\text { Household } \\
\text { of } 1 \text { person } \\
\text { (worked) }\end{array}$} & \multicolumn{2}{|c|}{$\begin{array}{l}\text { Household of } \\
2 \text { persons } \\
\text { (all are } \\
\text { worked) }\end{array}$} & \multicolumn{2}{|c|}{$\begin{array}{c}\text { Household of } \\
3 \text { persons } \\
(2 \text { are worked }+ \\
1 \text { child })\end{array}$} & \multicolumn{2}{|c|}{$\begin{array}{l}\text { Household of } \\
4 \text { persons } \\
\text { ( } 2 \text { are worked }+ \\
2 \text { children) }\end{array}$} \\
\hline & & & & UAH & $\%$ & UAH & $\%$ & UAH & $\%$ & UAH & $\%$ & UAH & $\%$ \\
\hline & 1 & & 2 & 3 & 4 & 5 & 6 & 7 & 8 & 9 & 10 & 11 & 12 \\
\hline \multirow{21}{*}{ 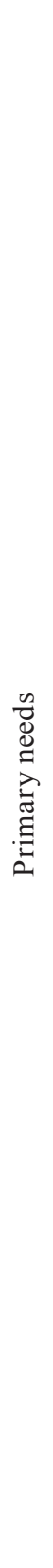 } & & A & $\begin{array}{l}\text { Mandatory monthly } \\
\text { expenses, including: }\end{array}$ & 2882,4 & 90,1 & 5531,3 & 84,0 & 9287,3 & 70,5 & 11299,9 & 85,8 & 11703,9 & 88,8 \\
\hline & & & power supply, including: & 1040,0 & 32,5 & 1613,8 & 24,5 & 2743,4 & 20,8 & 3429,3 & 26,0 & 3772,2 & 28,6 \\
\hline & & $a_{1}$ & $\begin{array}{l}\text { goods are the first } \\
\text { necessity (bread, butter, } \\
\text { meat, fish, etc.) }\end{array}$ & 550,4 & 17,2 & 856,3 & 13,0 & 1455,7 & 11,1 & 1819,6 & 13,8 & 2001,6 & 15,2 \\
\hline & & & vegetables & 288,0 & 9,0 & 474,2 & 7,2 & 806,2 & 6,1 & 1007,8 & 7,7 & 1108,6 & 8,4 \\
\hline & & & fruit & 201,6 & 6,3 & 283,2 & 4,3 & 481,5 & 3,7 & 601,9 & 4,6 & 662,1 & 5,0 \\
\hline & & & $\begin{array}{l}\text { communal payments, } \\
\text { including: }\end{array}$ & 518,4 & 16,2 & 901,2 & 13,7 & 1045,5 & 7,9 & 1108,8 & 8,4 & 954,0 & 7,2 \\
\hline & $\underset{\Xi}{0}$ & & rent & 131,2 & 4,1 & 131,2 & 2,0 & 150,0 & 1,1 & 155,0 & 1,2 & 156,0 & 1,2 \\
\hline & $\frac{\Xi}{\mathbb{J}}$ & $a_{2}$ & water & 48,0 & 1,5 & 80,0 & 1,2 & 120,0 & 0,9 & 156,0 & 1,2 & 108,0 & 0,8 \\
\hline & $\frac{0}{0}$ & & gas & 297,6 & 9,3 & 580,0 & 8,8 & 638,0 & 4,8 & 643,8 & 4,9 & 580,0 & 4,4 \\
\hline & $\frac{\infty}{2}$ & & electric power & 41,6 & 1,3 & 110,0 & 1,7 & 137,5 & 1,0 & 154,0 & 1,2 & 110,0 & 0,8 \\
\hline & & $a_{3}$ & taxes & 624,0 & 19,5 & 1284,4 & 19,5 & 2418,0 & 18,4 & 2418,0 & 18,4 & 2418,0 & 18,4 \\
\hline & & $a_{4}$ & transport & 76,0 & 2,4 & 184,0 & 2,8 & 352,0 & 2,7 & 406,0 & 3,1 & 424,0 & 3,2 \\
\hline & & $\mathrm{a}_{5}$ & $\begin{array}{l}\text { manufactured goods } \\
\text { (clothing, chemistry) }\end{array}$ & 572,8 & 17,9 & 1449,1 & 22,0 & 2608,4 & 19,8 & 3477,8 & 26,4 & 3622,7 & 27,5 \\
\hline & & $a_{6}$ & $\begin{array}{l}\text { telecommunication } \\
\text { services (internet }+ \\
\text { mobile phone) }\end{array}$ & 51,2 & 1,6 & 98,8 & 1,5 & 120,0 & 0,9 & 130,0 & 1,0 & 150,0 & 1,1 \\
\hline & & $a_{7}$ & children development & 0 & 0 & 0 & 0 & 0 & 0 & 330,0 & 2,5 & 363,0 & 2,8 \\
\hline & & B & Recurrent costs & 80,0 & 2,5 & 157,6 & 2,4 & 310,1 & 2,4 & 384,7 & 2,9 & 386,4 & 2,9 \\
\hline & & $b_{1}$ & loans and bank. services & 0 & 0 & 0 & 0 & 0 & 0 & 0 & 0 & 0 & 0 \\
\hline & 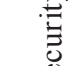 & $b_{2}$ & insurance & 3,2 & 0,1 & 3,2 & 0,05 & 6,4 & 0,1 & 6,4 & 0,04 & 0 & 0 \\
\hline & $\begin{array}{l}\infty \\
0 \\
\dot{0}\end{array}$ & $b_{3}$ & repairs & 3,2 & 0,1 & 3,2 & 0,05 & 4,2 & 0,03 & 4,5 & 0,03 & 5,1 & 0,04 \\
\hline & ర્ల & $\mathrm{b}_{4}$ & appliances & 3,2 & 0,1 & 3,2 & 0,05 & 3,5 & 0,03 & 3,8 & 0,03 & 3,8 & 0,03 \\
\hline & & $\mathrm{b}_{5}$ & medical services & 70,4 & 2,2 & 148,0 & 2,2 & 296,0 & 2,2 & 370,0 & 2,8 & 377,4 & 2,9 \\
\hline
\end{tabular}


Continuation of Table 2

\begin{tabular}{|c|c|c|c|c|c|c|c|c|c|c|c|c|c|}
\hline \multicolumn{3}{|c|}{1} & 2 & 3 & 4 & 5 & 6 & 7 & 8 & 9 & 10 & 11 & 12 \\
\hline \multicolumn{3}{|c|}{$\mathrm{C}$} & Optional expenses & 163,2 & 5,1 & 224,0 & 3,4 & 378,7 & 2,9 & 421,6 & 3,2 & 312,2 & 2,4 \\
\hline \multirow{14}{*}{ 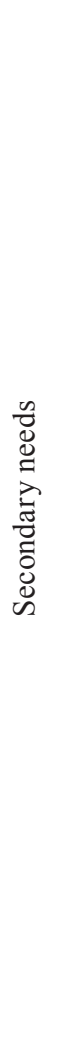 } & \multirow{4}{*}{ 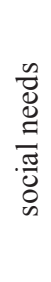 } & $\mathrm{c}_{1}$ & luxuries & 0 & 0 & 0 & 0 & 0 & 0 & 0 & 0 & 0 & 0 \\
\hline & & $\mathrm{c}_{2}$ & entertainment & 0 & 0 & 32,9 & 0,5 & 56,0 & 0,4 & 62,6 & 0,5 & 0 & 0 \\
\hline & & $\mathrm{c}_{3}$ & $\begin{array}{l}\text { recreation and } \\
\text { recreation }\end{array}$ & 80,0 & 2,5 & 85,6 & 1,3 & 154,1 & 1,2 & 179,8 & 1,4 & 154,1 & 1,2 \\
\hline & & $\mathrm{c}_{4}$ & $\begin{array}{l}\text { education, personal } \\
\text { development (books, } \\
\text { magazines, seminars) }\end{array}$ & 83,2 & 2,6 & 105,4 & 1,6 & 168,6 & 1,3 & 179,2 & 1,4 & 158,1 & 1,2 \\
\hline & \multicolumn{2}{|c|}{$\mathrm{D}$} & Unplanned expenses & 73,6 & 2,3 & 118,6 & 1,8 & 205,5 & 1,6 & 229,2 & 1,7 & 169,9 & 1,3 \\
\hline & \multirow{3}{*}{\multicolumn{2}{|c|}{ 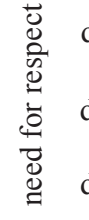 }} & donations, volunteering & 0 & 0 & 0 & 0 & 0 & 0 & 0 & 0 & 0 & 0 \\
\hline & & & holidays & 44,8 & 1,4 & 79,0 & 1,2 & 138,3 & 1,1 & 146,2 & 1,1 & 86,9 & 0,7 \\
\hline & & $\mathrm{d}_{3}$ & $\begin{array}{c}\text { other (expenses for } \\
\text { household) }\end{array}$ & 28,8 & 0,9 & 39,5 & 0,6 & 67,2 & 0,5 & 83,0 & 0,6 & 83,0 & 0,6 \\
\hline & \multicolumn{2}{|c|}{$\begin{array}{c}=\sum(\mathrm{A} \\
\mathrm{B}, \mathrm{C}, \mathrm{D})\end{array}$} & Family expenses & 3199,2 & 100,0 & 6031,4 & 91,6 & 10181,6 & 77,3 & 12335,4 & 93,6 & 12572,4 & 95,4 \\
\hline & \multicolumn{2}{|c|}{$\mathrm{S}$} & Investments & 0 & 0 & 555,4 & 8,4 & 2992,0 & 22,7 & 838,2 & 6,4 & 601,2 & 4,6 \\
\hline & \multirow{4}{*}{ 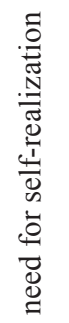 } & $\mathrm{s}_{1}$ & savings in cash & 0 & 0 & 55,4 & 0,8 & 492,0 & 3,7 & 338,2 & 2,6 & 101,2 & 0,8 \\
\hline & & $\mathrm{s}_{2}$ & bank deposits & 0 & 0 & 500,0 & 7,6 & 1000,0 & 7,6 & 500,0 & 3,8 & 500,0 & 3,8 \\
\hline & & $\mathrm{s}_{3}$ & $\begin{array}{l}\text { investments in securi- } \\
\text { ties, invest. foundations }\end{array}$ & 0 & 0 & 0 & 0 & 0 & 0 & 0 & 0 & 0 & 0 \\
\hline & & $\mathrm{s}_{4}$ & $\begin{array}{l}\text { development of own } \\
\text { business }\end{array}$ & 0 & 0 & 0 & 0 & 1500,0 & 11,4 & 0 & 0 & 0 & 0 \\
\hline \multirow{6}{*}{ 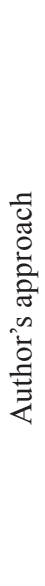 } & $\begin{array}{l}\sum(\mathrm{A} \\
\mathrm{C}, \mathrm{D}\end{array}$ & $\begin{array}{l}\mathrm{B} \\
\mathrm{X})\end{array}$ & $\begin{array}{l}\text { Amount of family ex- } \\
\text { penses and investments }\end{array}$ & 3200,0 & 100 & 6586,8 & 100 & 13173,6 & 100 & 13173,6 & 100 & 13173,6 & 100 \\
\hline & C & G & $\begin{array}{l}\text { Income/return on } \\
\text { investment }\end{array}$ & 0 & 0 & 80,0 & 1,2 & 385,0 & 2,9 & 80,0 & 0,6 & 80,0 & 0,6 \\
\hline & \multirow{3}{*}{$\begin{array}{l}0 \\
\Xi \\
\Xi \\
\Xi \\
\Xi \\
\Xi \\
\Xi \\
0 \\
\Xi \\
\Xi \\
0 \\
\Xi \\
0 \\
0\end{array}$} & $g_{1}$ & $\begin{array}{l}\text { banks. deposit } \\
\text { (16\% per annum) }\end{array}$ & 0 & 0 & 80,0 & 1,2 & 160,0 & 1,2 & 80,0 & 0,6 & 80,0 & 0,6 \\
\hline & & $\mathrm{g}_{2}$ & $\begin{array}{l}\text { dividends from deposits } \\
\text { in securities }\end{array}$ & 0 & 0 & 0 & 0 & 0 & 0 & 0 & 0 & 0 & 0 \\
\hline & & $\mathrm{g}_{3}$ & $\begin{array}{c}\text { profit from own } \\
\text { business ( } \mathrm{R}=15 \%)\end{array}$ & 0 & 0 & 0 & 0 & 225,0 & 1,7 & 0 & 0 & 0 & 0 \\
\hline & \multicolumn{2}{|l|}{$\mathrm{Y}$} & $\begin{array}{l}\text { Aggregate family } \\
\text { income }\end{array}$ & 3200,0 & $\mathrm{X}$ & 6666,8 & $\mathrm{X}$ & 13558,6 & $\mathrm{X}$ & 13253,6 & $X$ & 13253,6 & $\mathrm{X}$ \\
\hline
\end{tabular}

Note: the authors own development using the data [1, 10], as well as surveys conducted on Internet portals

In fact, through this assessment, the difficult conditions for the survival of a potential domestic investor (households of different types) are characterized. Although with the participation of the Cabinet of Ministers of Ukraine from the beginning was carried out a certain transition from the minimum wage in 1429.3 UAH up to $3200 \mathrm{UAH}$ (in the future up to $4173 \mathrm{UAH}$ - during 2018) [10], but in general, the income level of households leaves much to be desired.

Any family (judging by the results of the presented studies) has to save on primary needs, not to mention secondary. The majority of the interviewed families $(84 \%)$ receive subsidies from the state to pay utility bills, otherwise their share in expenses may rise to $60 \%$. The family has to save on the development of children, their own development, and this does not contribute to the formation of such social environment, to which Ukraine aspires. 
So, for the process of investing a family, the profitability and riskiness of various investment options are analyzed, taking into account the provision of reliable and effective management of their funds. If analyze the statistics of changes in the exchange rate, then over the past five years, the NBU rate of the dollar against the hryvnia increased from 7.99 UAH for 1 US dollar - on 1.01.2013 to 27.16 UAH - as of December 1, 2017 [11]. This indicates that during this period, the hryvnia depreciated by $19.17 \mathrm{UAH}$, which led to higher prices for consumer goods, gas, fuel, energy, that is, as a whole. It is considered that the population is forced to spend the savings that are collected in previous years or to withdraw them from investments.

In addition, the situation when households tend to invest money is analyzed, that is, to act as domestic investors of the state. It is another matter that the state gives them such opportunity even with such strong "family" economy.

An analysis of the categories of consumption, savings and investment indicates that among the many factors that affect the amount of consumer spending, the main thing is the level of income of families after paying taxes. It is also proved that the increase in incomes entails also an increase in savings and, correspondingly, an increase in expenditures (for food, clothing, recreation, etc.). This fully corresponds to Engel's law [3], according to which, with the growth of family incomes, the share of expenditure on food is reduced, the share of expenditures for the purchase of clothing, housing and utilities is not changing significantly, and the share of expenses for satisfying cultural and other intangible needs significantly increases.

The results of the study also correspond to the law of Keynes [5] on the emergence of the need for investment only when income exceeds consumption, and then only as part of the so-called "preservation". So, if to assume that it is able to invest, it would mean that consumption is reduced or income is increased. Thus, with a constant family income, a decrease in consumption leads to an increase in savings and investment opportunities.

Perceived logical chain between the level of development of the state and the incomes of its population which is able to invest, corresponds to the theory of M. Tugan-Baranovsky [3] on the impact of income growth and household income, through the investment process, the potential enrichment of the state as a whole and its emergence from a crisis.

So, the state should not stand aside investment processes. This coincides with the theoretical postulates of A. Wagner [4], J. Keynes [5, p.150] and his followers on the necessity of allowing state intervention in the regulation of the country's socioeconomic development, in particular with a view to intensifying domestic investment.

\section{Research results and their discussion}

The calculations show that the amount of income is crucial in the formation of savings, and this in turn affects investment in general. All this shows that with the maximum income of families, regardless of the number of people members, there is an opportunity to invest of savings. With minimal income, there are no savings at all, as are non-mandatory expenses and unplanned ones, that is, the secondary needs are not actually met. With the maximum income, the opportunity for investment appears at the reduction of the total mandatory monthly expenses, with a sufficiently large periodic expenditure, unplanned and non-compulsory expenses.

The mathematical model proposed in this article actually allows to combine the level of family income with the level of state development and to lay the economic foundation in the state's calculations on what the incomes of the population should be, so that it becomes able to invest.

So, in the presented mathematical model, the basic level of family income is the key indicator, which includes consumption and savings, and savings, in turn, provide a choice: to invest savings in their own business, place a deposit in the bank, or keep them "under the pillow " - in that case they do not work for the economy, but it is a means for confidence in the future for the person or his family, it is also possible to combine these options.

In fact, even for very economical Ukrainians (identified by the results of this survey), the main problem is low income. So, the complexity of the economic situation in Ukraine is indicated by the fact that of the estimated household savings in cash (which can be called "zero" - invest- 
ment) occupy no more than $1 \%$ for households with an average income with 1 working without children and for households of 2 working and 2 children. For households of 1 working, having a minimum level of income, there are no savings at all, not to mention a full-fledged investment. Even for the most anticipated potential investors - households with an average income level - savings in cash take from 2.5 to $4 \%$.

Ukrainian families are eager to invest. The proof is the fact that Ukrainians try hard not to save their money in cash, but to invest in the form of bank deposits. For example, middle-income families, consisting of 1 and 2 working children who do not have children, allocate about $8 \%$ of their incomes for this type of investment, and it lays a certain potential for their future development. For middle-income families with children, the situation looks more modest, because they can't deposit more than $4 \%$.

Also, families of 2 workers and 1 child with middle income often resort to investing in the development of their own business, usually outside the main work. Deposits in this area of investment are more than $10 \%$. This can be regarded as an indirect signal for the revival of small businesses in Ukraine.

All three types of investing, applied by the Ukrainian, allow them to earn from 0.5 to $3 \%$ besides the income from core business.

This model can be used by any person (family) who wants to evaluate the structure of their expenses. After correlating the characteristics of his family with the one derived in Table 2 potential structure of incomes and expenses, everyone can thoroughly approach to planning of the expenses and investments.

This model can also be useful for the authorities, justify, on the one hand - minimum wages and subsistence minimum, and on the other hand, for example - tariffs for utilities in these economic conditions.

This proves the need for the state to participate in creating favorable conditions for the development of the economy, business, and financial institutions. The guarantee of the state in the reliability of such institutions must become an obligatory condition, and only under such conditions the savings of the population will turn into investments. This will facilitate access to investment resources within the state without attracting or minimally dependent on external (international) loans. Only under such conditions, according to the authors, the internal market of investment resources will develop, one of the main sources of which will become the population. This will revive the emergence and implementation of new investment proposals for the state, business, etc., but when the state fulfills one, the main condition is availability of guarantees: return - preservation - increasing the population's deposits, business justice, competitive economy, and the like.

In addition, from the side of the state it is necessary through the media and other means of communication to show the population the opportunities and various alternatives to the allocation of monetary resources, to prove the effectiveness of their use, security (first of all, on the return of deposits), that is, the state should mediate, guarantee relations between business and population.

Therefore, no matter how the priority of the strategic development of our state (its regions, their individual foreign trade activities) is chosen, there will be a question of sources of financing for their development. External investments will necessarily come if there is a profit, but an additional indicator of stability can be investment from domestic sources. It should also be taken into account that attracting an external investor with a low level of domestic investment, in addition to providing sufficient profitability (ROI) will require additional guarantees or other preferences for these investors. The cost of investments in the domestic market is lower than attracting them from outside by reducing the cost of intermediaries and because of the absence of a difference in exchange rates. According to the conclusion, the state itself is obliged to create conditions for the emergence and formation of a cohort of domestic investors.

Each state can find its own way, taking into account the experience of other countries and remembering its history. Ukraine is a rich country not only with natural resources, it has a powerful and irresistible resource - an active population. Obviously, when creating the appropri- 
ate conditions for the population will get a push to intensive business and investment activities. Therefore, further research should be devoted to the creation of attractive conditions for the support and development of the domestic investor, since the prospects for the development of a favorable investment environment in the state and its regions are possible primarily through the disclosure of internal potential - thanks to the available resources invested and used for the evolution of domestic markets.

\section{Conclusions}

The conducted research allows to draw the following conclusions:

1. The classical theories of a number of well-known economists (E. Engel, A. Wagner, M. Tugan-Baranovsky, J. Keynes, P. Samuelson) on the relationship between consumption, savings and investment categories that combine the level of households and the level of the state into a single system, are still effective today, which is proved by the conducted research of Ukrainian realities.

2. Based on the study of empirical data (primary survey), a mathematical model and an algorithm for determining the minimum level of the aggregate family income necessary for its transition to the rank of an internal investor of the state (on Ukrainian data) are developed.

3. The conditions in which the domestic investor is now located (for Ukraine) are determined. The ability of the population to save under the current economic conditions is estimated. The averaged family spending structure is constructed and the saving component is selected, which under favorable conditions is transformed into investments, which are the generator of economic development of the state.

4. The role and influence of the state on creating conditions for the reproduction and development of the labor potential of the population of the state is determined. The investment components in savings, as well as savings - in wages have been determined, and their potential impact on the effective development of the state has been assessed.

5. The real minimum income level (for families of different composition), which will allow them to go from survival to their own development, with the transition to investment, will be useful both for the legislative activity of the state and for the population (households).

\section{References}

[1] Demohrafichna ta sotsial'na statystyka [Demographic and social statistics]. Sayt Derzhavnoyi sluzhby statystyky Ukrayiny [Site of The State Statistics Service of Ukraine]. Available at: http:// www.ukrstat.gov.ua/

[2] Jahan, S. (2016). Human Development Report 2016. United Nations Development Program. Available at: http://hdr.undp.org/sites/default/files/2016_human_development_report.pdf

[3] Fetisov, G. G. (Ed.) (2004-2005). Mirovaшa ekonomicheskaша mysl'. Skvoz' prizmu vekov [World economic thought. Through the prism of the centuries]. Vols. 1-5. Moscow: Mysl', 720, 752, 896, 896,816 .

[4] Yukhymenko, P. I., Fedosov, V. M., Lazebnyk, L. L. et. al.; Fedosov, V. M., Yuriy, S. I. (Eds.) (2010). Teoriya finansiv [Theory of finance]. Kyiv: Tsentr uchbovoyi literatury, 576.

[5] Hayes, M. G. (2006) The Economics of Keynes: A New Guide to the General Theory. Cheltenham, Northhampton: Edward Elgar Publishing, 257.

[6] Samuelson, P., Nordhaus, W. (2009). Economics (19th ed.). New York: McGraw-Hill Higher Education, 744.

[7] Bandera, V., Bunyak, V., Vatamanyuk, O., Dorofeyeva, N., Korotka, H.; Panchyshyn, S., Savluk, M. (Eds.) (2003). Dokhody i zaoshchadzhennya v perekhidniy ekonomitsi Ukrayiny [Income and savings in transitional economy of Ukraine]. Lviv: Vydav. tsentr LNU im. I. Franka, 406.

[8] Kluchnyk, L. V. (2012). Zaoshchadzhennya domashnikh hospodarstv yak dzherelo investytsiynykh resursiv ekonomiky Ukrayiny [The savings of the households as a source of investment resources of the Ukrainian economy]. Ekonomichni nauky. Seriia: Oblik i finansy [Economic sciences. 
Series: Accounting and Finance], 9 (4), 159-166. Available at: http://nbuv.gov.ua/j-pdf/ecnof_2012 9(4)__20.pdf

[9] Petrenko, I. P. Transformatsiya zaoshchadzhen' naselennya v investytsiyi: dosvid ta problemy v Ukrayini [Household savings transformation into investments: practice and problems in Ukraine]. Ekonomika Ukrayiny [Economy of Ukraine], 3, 50-61. Available at: http://nbuv.gov.ua/j-pdf/ EkUk_2014_3_5.pdf

[10] Zarobitna plata v Ukrayini [Salaries in Ukraine]. Finansovyy portal MINFIN [Financial Portal MINFIN]. Retrieved from https://index.minfin.com.ua/ua/labour/salary/

[11] Arkhiv kursiv NBU [Archive of NBU courses]. Finansovyy portal MINFIN [Financial Portal MINFIN]. Available at: http://index.minfin.com.ua/arch/

[12] Polishchuk, N. (2015). Minimal'na zarobitna plata sered krayin svitu ta v Ukrayini (dynamika ta heohrafiya 2005-2015 rr.) [The minimum salary among the countries of the world and in Ukraine (dynamics and geography of 2005-2015)]. Infolight: informatsiyno-analitychnyy tsentr [Infolight: Information Analysis Centre]. Available at: http://infolight.org.ua/content/minimalna-zarobitna-plata-sered-krayin-svitu-ta-v-ukrayini-dynamika-ta-geografiya-2005-2015-rr

[13] Bourgeais, V. (2017). National minimum wages in the EU. Eurostat. Available at: http:// ec.europa.eu/eurostat/documents/2995521/7860532/3-10022017-AP-EN.pdf 